\title{
Reversing Agro-Based Land Degradation through Conservation Agriculture: Emerging Experiences from Zambia's Smallholder Farming Sector
}

\author{
Bridget Bwalya Umar ${ }^{1}$ \\ ${ }^{1}$ Department of International Environment and Development Studies, Norwegian University of Life Sciences, \\ Norway \\ Correspondence: Bridget Bwalya Umar, Department of International Environment and Development Studies, \\ Norwegian University of Life Sciences, Norway. Tel: 47- 6496-5340. E-mail: brigt2001@yahoo.co.uk
}

Received: May 22, 2012 Accepted: June 28, 2012 Online Published: July 8, 2012

doi:10.5539/sar.v1n2p72 URL: http://dx.doi.org/10.5539/sar.v1n2p72

\begin{abstract}
This study reports on the land degradation minimizing effects of Conservation Agriculture (CA) as promoted among smallholder Zambian farmers. It found no evidence of CA associated improvements in soil fertility after five years of CA practice, most probably because crop residues were removed from the fields. The study reports high phosphorus $\left(15.53 \mathrm{mg} \mathrm{kg}^{-1}\right)$ and potassium $\left(0.75 \mathrm{cmol} \mathrm{kg}^{-1}\right)$ levels, low nitrogen $(0.12 \%)$ and organic carbon (1.19\%) levels, and no plough/hoe pans in soils from both CA and conventionally (CV) managed fields. This is in part contrary to the dominant land degradation narratives which have been the basis for promoting CA in the study areas. Faidherbia albida, a leguminous tree promoted as part of the CA package in Zambia, is associated with significantly higher levels of nitrogen, organic carbon and potassium under its canopy. Its planting by CA farmers is linked to the incentives provided by CA promoters. Average maize yields of $3.8 \mathrm{tha}^{-1}$ and $2.8 \mathrm{tha}^{-1}$ were reported under CA and CV systems respectively. Government subsidies for mineral fertilizer and hybrid seed promote maize mono-cropping and remain unsupportive of $\mathrm{CA}$. It is concluded that the dominant land degradation narrative, which posits population induced land degradation, may not hold in this case. Instead, the removal of crop residues and low levels of mineral fertilizer and manure amendments may better explain the soil fertility status of the study areas. More nutrient replacement strategies are required if the benefits of CA on soil fertility are to be actualized in the immediate future.
\end{abstract}

Keywords: nutrient mining, land degradation, crop residues, Neo-Malthusian narrative, Faidherbia albida

\section{Defining Land Degradation}

The United Nations Convention to Combat Desertification (UNCCD) defines land degradation as "the reduction or loss, in arid, semi-arid and dry sub-humid areas, of the biological or economic productivity and complexity of rain fed cropland, irrigated cropland, or range, pasture, forest and woodlands resulting from land uses or from a process or combination of processes, including processes arising from human activities and habitation patterns"(United Nations, 1994:p5). An article in a recent special issue of the journal Land Degradation and Development on the recommendations that emerged from the first scientific conference commissioned by the UNCCD clarified that it is not any reduction in the biological or economic productivity that constitues land degradation, but a process of persistent reduction or loss of biological productivity (Vogt et al., 2011: emphasis in original). Somasiri (1994) argues that land degradation is a serious threat to social, economic and political stability in developing countries. Ayoub (1994) reported that in Africa, land degradation is characterized by soil erosion. In this paper, land degradation is considered to be simply the reduction in agricultural productivity resulting from agricultural practice.

The low agricultural productivity and associated poverty in Sub-Saharan Africa (SSA) have been linked to land degradation. The dominant narrative, known as the Classic (Biot, Blaikie, Jackson, \& Palmer-Jones, 1995) or Neo-Malthusian approach, argues that poor agricultural practices, in combination with population growth and poverty, are the underlying causes of land degradation in the region. Declining soil fertility, particularly nutrient mining, is reported to be widespread and a major threat to food and livelihood security across SSA (Scoones, 2001; Heerink, 2005; Vlek \& Tamene, 2009). Approximately 65\% of Africa's population experiences effects of 
land degradation while about three per cent of GDP from agriculture is lost every year because of loss of nutrients from the soil (Drechsel, Gyiele, Kunze, \& Cofie, 2001a). Farming households have responded to the decline in land productivity by abandoning degraded agricultural fields and converting new lands for agricultural production (Barbier 2000; Diagana, 2003). Due to lack of soil conservation measures, this process of land degradation and conversion repeats itself (Barbier, 2000; Reij \& Smaling, 2008). Rockström et al. (2009) contended that a major driver behind land degradation causing current low yield levels in East and Southern Africa is intensive land preparation through hoeing or ploughing in conjunction with non retention of crop residues, left the soil susceptible to rain, wind and sun.

The Classic or Neo-Malthusian narrative on land degradation ends with identifying population pressure, poverty and poor agricultural practices by smallholder farmers as inducing land degradation without analyzing the underlying causes. It has thus been criticized as being apolitical and ignoring the incentivizing role of existing socio-economic policy environments which lead smallholders to respond in ways that are detrimental to the environment (Diagana, 2003). The Economic or Neo-liberal approach focuses on the policy environment. Proponents of this approach contend that it is necessary to comprehend the structures of incentives that discourage land users from adopting sustainable technologies (Biot et al., 1995). They assert that 'pull' and 'push' factors are important in explaining land degradation in SSA. On the one hand, push factors like high population growth lead to unsustainable inter-relations among population, agriculture and the environment that in turn result into a poverty trap (Drechsel, Kunze, \& de Vries, 2001b). On the other hand, pull factors like market failures weaken the incentive system and inhibit long - term investment in soil conservation. Distorted public price and trade policies, high transaction costs due to poor infrastructure, and insecure property rights create further disincentives to invest in agriculture (Diagana, 2003).

There have been increasing calls for the development of sustainable agricultural production systems that serve the dual role of increasing agricultural productivity and enhancing the environment through restoration of degraded agricultural lands (Kassam \& Friedrich, 2010). Such systems, combined with better designed agro economic policies could significantly mitigate some aspects of land degradation in Africa, and at the same time enhance the livelihoods of the poor, especially those based in rural areas (Babier, 2000). One such alternative agricultural system being promoted is Conservation Agriculture (CA). The Food and Agricultural Organization (FAO) (FAO, 2011a) defines CA as an approach used to manage agro-ecosystems in a way that raises profits and improves food security; and enhances the resource base while sustaining or improving productivity. CA is based on the simultaneous application of three principles namely minimum tillage; permanent soil cover with organic materials such as crop residues or cover crops; and diversified crop rotations (FAO, 2010). Vlek \& Tamene (2009) predicted that expansion of CA could lead to a win-win situation by creating more efficient crop producting and land degradation reducing systems, while maintaining ecosystem integrity. Lahmar, Bationo, Lamso, Guero, \& Tittonell, 2011) posited that the most prominent aspect of CA for degraded lands in the semi-arid tropics is the organic soil cover that impacts on soil water balance, biological activity, soil organic matter build-up, and fertility replenishment.

Marongwe and colleagues (2011) speculated that the longer term benefits of CA systems could have an impact on mitigating the effects of climate change and land degradation. Other observers have reported that CA helps to enhance the stability of soil aggregates (Hobbs, 2007). Retaining crop residues helps retain soil particles and the associated nutrients on the field (Reicosky, 2009; Varvel \& Wilhelm, 2011).

\subsection{Land Degradation and Conservation Agriculture in Zambia}

Land degradation has reportedly occurred in Zambia as a result of unsustainable farming practices such as shifting cultivation, continuous mono-cropping and over-grazing. These practices, in combination with wood fuel and charcoal production, are said to have caused deforestation, soil erosion and biodiversity loss. Land degradation is severe in the Central, Eastern, Southern, Western, and Lusaka Provinces of Zambia; and has resulted in low land productivity, and concomitantly low crop and animal productivity and animal diseases. Given that an overwhelming majority of the rural population depends on agriculture, the effect of land degradation is deepening of rural poverty (GRZ 2002: xii-xiii).

CA promotion in Zambia lies within both the Neo-Malthusian and Neo-liberal land degradation narratives. According to Haggblade and Tembo (2003), the heavy application of subsidized mineral fertilizers from the early 1970's until 1991, combined with low levels of organic material amendments, led to serious land degradation characterized by erosion, acidification, reduction in Soil Organic Matter (SOM) and a buildup of plough pans across much of the southern half of the country. The Conservation Farming Unit (CFU) (CFU, 2006) identified Zambia's historical and continuing fixation on maize and mineral fertilizers as being responsible for what it 
described as inefficient, exploitative and environmentally destructive farming practices. Producer subsidies for mineral fertilizer and maize had encouraged the extension of maize cultivation into unsuitable areas (Deininger \& Olinto, 2003) with concomitant decreased soil fertility, degradation of natural resources, and inefficiency in human resource utilization (Siegel \& Alwang, 2005). Subsistence farming reportedly failed to maintain soil fertility which broke down due to population pressure (Franzel, 1999; Opio, 2001; Kwesiga, Akinnifesi, Mafongoya, McDermott, \& Agumya, 2003). Ajayi, Place, Kwesiga and Mafongoya (2006) noted that fallow periods had been shortened and were no longer able to restore soil fertility. They argued that although mineral fertilizers could be used in place of fallows, farmers in Africa apply only paltry amounts of around eight kilograms per hectare of mineral fertilizer while the global average is 100 kilograms per hectare (Alliance for a Green Revolution in Africa [AGRA], 2011). In order to maintain total production, cultivated land is extended by converting forests into agricultural fields. Area expansion or shifting cultivation is a major cause of deforestation in Zambia (Provincial Forestry Action Programme [PFAP], 2005; Government of the Republic of Zambia [GRZ], 2010).

Conservation Agriculture as promoted among smallholder farmers in Zambia consists of a package of various agronomic practices: dry-season land preparation using locally tailored minimum tillage systems (manual and traction); retention of crop residues; micro-dosing of inputs such as seeds, lime, mineral and organic fertilizers; nitrogen-fixing crop rotations; timely sowing of crops; and the management of the leguminous tree Faidherbia albida. Recommended practice of manual CA in Zambia suggests digging basins with a length of $30 \mathrm{~cm}$, a width of $15 \mathrm{~cm}$ and a depth of $20 \mathrm{~cm}$. The basins are interspaced in a $70 \mathrm{~cm}$ x $90 \mathrm{~cm}$ matrix resulting in 15850 basins per hectare. At $0.045 \mathrm{~m}^{2}$ per basin, the total area covered by basins is $713 \mathrm{~m}^{2}$ per hectare, representing $7 \%$ of soil disturbance (FAO, 2011a:14). Traction CA prescriptions involve making furrows that are $15-20 \mathrm{~cm}$ deep at $90 \mathrm{~cm}$ spacing. This is equivalent to tillage on approximately $10-12 \%$ of the land (CFU, 2009a:10).

The Zambia National Farmers Union (ZNFU) established the Conservation Farming Unit (CFU) in 1995 which is mandated to lead the extension and development of CA technologies for smallholder farmers. In 2007 the CFU embarked on a five - year programme entitled Reversing Food Insecurity and Environmental Degradation in Zambia through Conservation Agriculture. The goals of the programme are to increase food security and profitability; to help smallholder farmers respond appropriately to emerging economic opportunities, and to encourage environmental regeneration (CFU, 2006) through the promotion of CA.

This paper examines if and how the practice of CA among smallholder farmers in Zambia is contributing to the reversing of agro-based land degradation. The investigation is limited to on-farm effects. Relevant national policies are analyzed to determine whether the policy environment in the agriculture sector is supportive of CA based soil fertility improvement. The appropriateness of the two land degradation narratives in explaining the results is discussed. No previous research has examined the relevance of the dominant land degradation narratives in informing the design and practice of CA in Southern Africa in general, and Zambia in particular. The paper finds that some of the premises for CA promotion in Zambia with regards to agro-based land degradation do not hold in the areas studied. This highlights the importance and need for the correct framing of problems since the framing of problems influences how programmes are designed and implemented, and ultimately impacts on their success.

\section{Methods}

The fieldwork was conducted between August 2007 and July 2010.

\subsection{Description of Study Areas}

Three provinces (Southern, Eastern and Central) were selected as study areas as they were known to have been the focus of CA promotion in the country, and also to capture the variations in agro-ecology (Figure 1). The study areas are situated in two of Zambia's three main agro-ecological regions which are referred to as AERs I, II, and III. The AERs are grouped based on duration of the growing season, topography, and average annual rainfall. AER II is further subdivided into IIa and IIb on the basis of differences in dominant soil type. AER I is a low rainfall, semi-arid region which receives a mean annual rainfall of below $800 \mathrm{~mm}$. It has an average growing season of 80 to 120 days and is at low altitudes ranging between 400 and $900 \mathrm{~m}$. AER II is a medium rainfall region and receives between 800 and $1000 \mathrm{~mm}$ of rainfall annually. Its growing season ranges between 100 and 140 days. It is a plateau region with altitudes of between 900 and 1300 m (GRZ, 2010). The study areas are located in AER I and IIa. The climate of the study areas is characterized by three distinct seasons; a warm-wet season (Nov-April), a cool-dry season (May-Aug) and a hot-dry season (Sept-Oct). Mean annual temperatures range between 23 and $32^{\circ} \mathrm{C}$. Dominant soils types in AER I are Haplic Luvisols, Haplic Solonertz and Dystic Leptosols. These soils are of low agricultural potential and are limited by lack of adequate water. AER IIa has 
moderately leached clayey to loamy soils of high agricultural potential. They are mainly Haplic Lixisols, Haplic Acrisols and Haplic Luvisols (Eroarome, 1983).

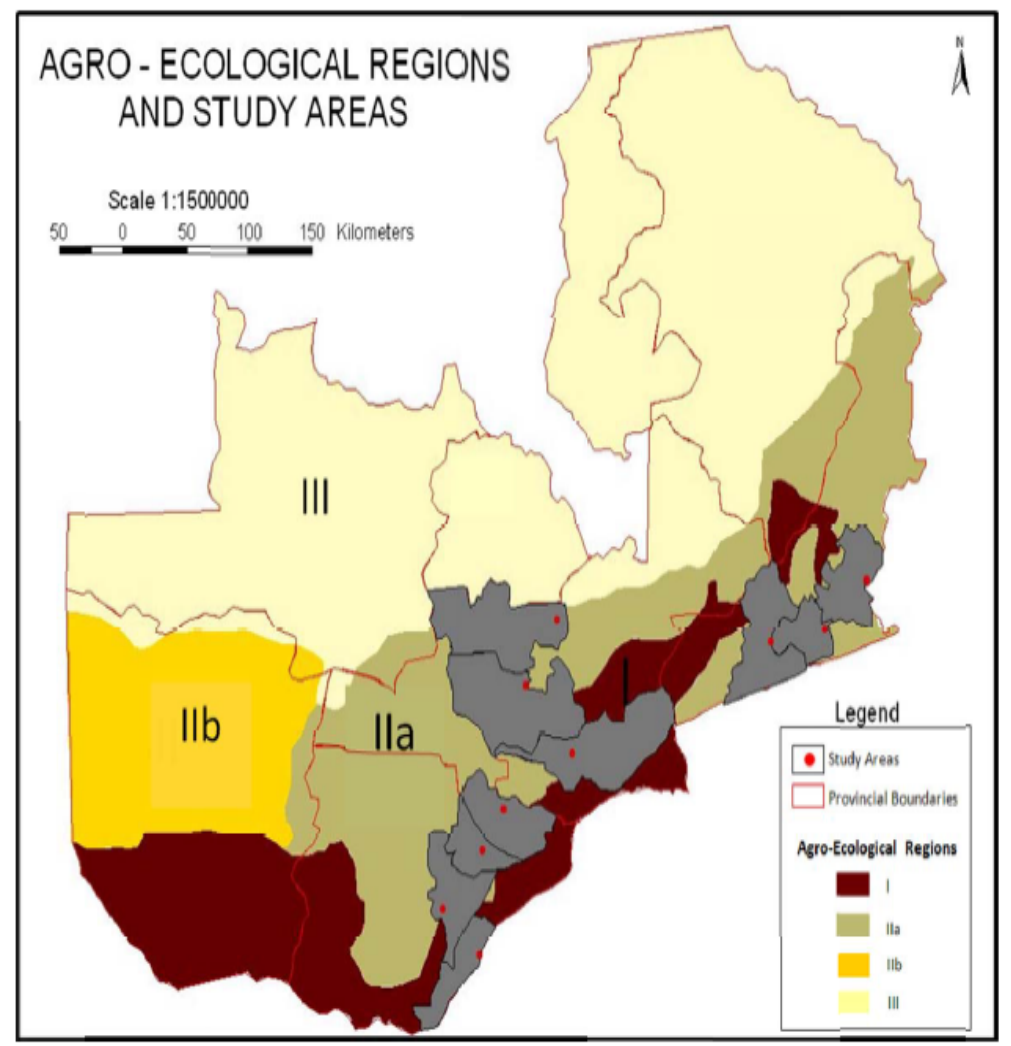

Figure 1. Map of Zambia showing agro-ecological regions and study areas

Smallholder farming is the most dominant livelihood activity in the study areas. Major crops grown are maize (Zea mays L.), the country's most important staple crop, cotton (Gossypium hirsutum L.), groundnuts (Arachis hypogaea L.), soyabeans (Glycine max L.), sorghum (Sorghum bicolor L.), cowpeas (Vigna unguiculata L.), sweet potatoes (Ipomea batatas L.), cassava (Manihot esculenta Crantz), common beans (Phaseolus vulgaris L.) and cucurbits. Mixed farming systems comprising both crop and livestock production dominate (Central Statistical Office [CSO], 2003). Total Livestock Units (Note 1) reported in literature are 4.1, 4.5 and 1.42 while contributions to these by cattle are $82 \%, 90 \%$ and $66 \%$ for the Southern, Central and Eastern Provinces respectively (GRZ, 2010). Smallholder farming is characterized by low productivity, with yields averaging only $50 \%$ of those achieved in the commercial farming sector. Farming operations are performed using hand tools and animal draft power. The use of external inputs is limited, and farming is mainly rain fed. They cultivate between two and five hectares of land (Chishala, 2007). The Eastern province, which is more intensively settled, has an average population density of 24.6 persons $\mathrm{km}^{-1}$ while the Southern and Central provinces have average population densities of 18.8 and 13.4 persons $\mathrm{km}^{-1}$ respectively (CSO, 2011). These figures are low by African standards (Ajayi et al., 2006: 1).

\subsection{Data Collection}

Several methods of data collection were used in this study. They included a panel household survey, semi-structured, and key informant interviews, field observations, focus group discussions, soil sampling, and a desk study of publications on CA.

\subsubsection{Questionnaire Survey}

A panel household survey was conducted annually from 2007 to 2010 . Half of the households to be interviewed were randomly selected from a list of CA adopters' lists in the Conservation Agriculture Programme (CAP) implemented by the CFU, while the rest were their nearest neighbor who was not on the CAP. A total of 640 households were interviewed in 2007, 535 in 2008, 486 in 2009, and 424 in 2010. The attrition was as a result of 
out-migration, death, refusal to be interviewed or unavailability of respondents during the survey period. In addition to the panel survey, data was collected from 129 households through semi-structured interviews in the same study areas between April and July 2009. These interviews probed the experiences of smallholders practicing CA in more detail than the larger panel survey was able to do. The results reported in this paper focus on CA practices with expected benefits on soil fertility such as minimum tillage; leguminous crop rotations; crop residue management; minimum mechanical soil disturbance; cover crops and agro-forestry; and manure and mineral fertilizer application. With the exception of one, all the CA households interviewed during the semi-structured interviews also had fields under conventional agriculture. Conventional Agriculture (CV) in Zambia refers to any farming method which involves complete soil inversion using a hand hoe, mould board plough or tractor. It is associated with removal of crop residues from the fields, and is often organized around the growing of maize.

\subsubsection{Focus Group Discussions and Key Informant Interviews}

Focus Group Discussions (FGD) were carried out in two groups of six and eight discussants, comprising both men and women CA farmers. Discussions focused on issues that had been highlighted in the semi-structured interviews as major challenges and benefits associated with CA such as crop yields, crop residue management, and the management of Faidherbia albida. The FGD were employed as a triangulation tool to see how the discussants responded to each other's views and whether the same issues were confirmed to be important when group dynamics were at play. Key informant interviews were conducted with agricultural extension officers involved in the promotion of $\mathrm{CA}$ in the study areas and researchers working on the development and dissemination of CA technologies in Zambia.

\subsubsection{Soil Sampling}

Two sets of soil samples were collected. The first set consisted of paired samples collected from CA and CV plots while the second set was made up of soil samples collected from around Faidherbia albida (Del.) trees.

\section{a. Paired samples from CA and CV plots}

The objective of this data collection method was to determine whether there were improvements in the soil fertility and soil structure in CA fields compared to CV fields. A total of 73 paired soil samples were collected. A pair was made up of one sample from a field under CV and another from a CA field. Details of the soil sampling procedure are outlined in Umar, Aune, Johnsen, \& Lungu (2011a). The soil samples were analyzed for organic carbon, soil reaction $(\mathrm{pH})$, bulk density, total nitrogen, exchangeable potassium, available phosphorus, and plant available water.

\section{b. Samples from under Faidherbia albida}

The goal of this data collection method was to determine the soil improving benefits of the leguminous tree Faideherbia albida. Three composite samples were taken at three different radii (inner, middle, outer) for each of the sampled 102 Faidherbia albida trees. Inner and middle radii fell under the tree canopy while the outer radius was outside (5m away) the tree canopy. Details of the soil sampling procedure are outlined in Umar, Aune \& Lungu (2011b).

\subsection{Statistical Analyses}

The quantitative data, that is soil analyses, panel survey and interview results, were analyzed with the use of paired sample T-Test, Analyses of Variance (ANOVA) and descriptive statistics using the statistical software MINITAB 15 for personal computers (Minitab, 2009), PASW/SPSS 18 (SPSS Inc, 2009) and R Studio (R Development Core Team, 2011). The statistical tests were conducted at a probability level of $\mathrm{p} \leq 0.05$.

\section{Results and Discussion}

\subsection{Minimum Tillage}

This study found that households practicing manual CA had an average of 21058 basins per hectare. This was a disturbance of $9.5 \%$ of the soil. The results for traction CA showed an average spacing of $100 \mathrm{~cm}$ between furrows. This translated into soil disturbance of between 9 and $11 \%$. This is a significant reduction in the percentage of soils inverted compared to conventional practice which involves complete soil inversion. The recommended depths of $20 \mathrm{~cm}$ were achieved for both CA systems.

Results indicated no significant differences in the bulk density, organic carbon, exchangeable potassium, total nitrogen, available phosphorus, soil reaction $(\mathrm{pH})$ or plant available water between paired samples from $\mathrm{CA}$ and $\mathrm{CV}$ plots (Table 1). CA had been practiced for an average of five years on the sampled fields while the CV fields had been under tillage for an average of 15 years. 
Table 1. Comparison of nutrient levels in conservation and conventional agricultural systems

\begin{tabular}{llll}
\hline & CA plot & CV plot & status \\
\hline Total N (\%) & $0.12^{\mathrm{a}}$ & $0.12^{\mathrm{a}}$ & low \\
& $(0.018)$ & $(0.017)$ & \\
Organic C (\%) & $1.19^{\mathrm{a}}$ & $1.22^{\mathrm{a}}$ & very low \\
& $(0.071)$ & $(0.078)$ & \\
$\mathrm{P}(\mathrm{mg} / \mathrm{kg})$ & $15.53^{\mathrm{a}}$ & $12.43^{\mathrm{a}}$ & high \\
& $(2.799)$ & $(1.771)$ & \\
$\mathrm{K}(\mathrm{cmol} / \mathrm{kg})$ & $0.75^{\mathrm{a}}$ & $0.73^{\mathrm{a}}$ & high \\
& $(0.034)$ & $(0.028)$ & \\
Bulk Density $\left(\mathrm{g} / \mathrm{cm}^{3}\right)$ & $1.42^{\mathrm{a}}$ & $1.44^{\mathrm{a}}$ & uncompacted soil \\
& $(0.027)$ & $(0.029)$ & \\
Plant Available Water $(\mathrm{v} / \mathrm{v})$ & $0.14^{\mathrm{a}}$ & $0.16^{\mathrm{a}}$ & normal \\
& $(0.012)$ & $(0.012)$ & \\
$\mathrm{pH}\left(\mathrm{CaCl}_{2}\right)$ & $5.44^{\mathrm{a}}$ & $5.26^{\mathrm{b}}$ & normal \\
$\mathrm{N}$ & $(0.079)$ & $(0.067)$ & \\
\hline
\end{tabular}

${ }^{a}$ means followed by the same letter in row were not significantly different at $p \leq 0.05$.

The values in parentheses are standard errors. Adapted from Umar et al. (2011a).

The low levels of total nitrogen and organic carbon in the soils from both CA and conventionally farmed plots was attributed to crop residue removal. The quantity of crop residues retained in the field influences the levels of organic carbon stored. These findings agree with those of Koga and Tsuji (2009) who did not find any significant changes in the organic carbon content from the top layers of soil profiles in Northern Japan. The reduction of tillage added organic carbon to the shallow layers of the soil (0-5 and 5-10 cm depths) only in cases where crop residues were retained in fields or manure was added to the soils.

While conventional tillage induces rapid mineralization of SOM and potential loss of carbon and nitrogen from the soil, reduced tillage promotes organic carbon stabilization in tropical and temperate soils (Chivenge, Murwira, Giller, Mapfumo, \& Six, 2007). In many situations, adoption of conservation tillage can reduce emissions of $\mathrm{CO}_{2}$ from the soil and effectively retain carbon in the soil (So, Kirchhof, Bakker, \& Smith, 2001). It is assumed that reductions in the SOC lost as a result of reduction in tillage occur gradually in the CA plots sampled during this study, as around $90 \%$ of the area remains undisturbed. However, Lal and Bruce (1999) cautioned that increasing the organic carbon content of soils in the tropics and subtropics is difficult and may lead to modest increases in organic carbon content of only $0.05 \mathrm{Mg} / \mathrm{ha} / \mathrm{yr}$ and carbon sequestration potential of about $0.04 \mathrm{Pg} / \mathrm{yr}$. It may be too early to expect significant SOC benefits resulting from CA in the areas studied.

\subsection{Crop Rotations, Cover Crops and Crop Residue Retention}

Crop rotations are practiced by a large majority of the households although with disproportionately larger areas allocated to maize compared to other crops (Table 2). 
Table 2. Crop rotation practices of CA farmers

\begin{tabular}{|c|c|c|c|}
\hline & $\begin{array}{l}\% \text { of households } \\
\text { including crop in } \\
\text { rotation* }\end{array}$ & $\begin{array}{l}\text { Area planted } \\
\text { to crop (ha)* }\end{array}$ & $\begin{array}{c}\text { Average crop } \\
\text { production } \\
(\mathrm{kg}) * / \text { household }\end{array}$ \\
\hline \multicolumn{4}{|l|}{ Non-legumes } \\
\hline Maize & 79.6 & 1.8 & 3026.9 \\
\hline Cotton & 36.3 & 1.2 & 789.2 \\
\hline $\begin{array}{l}\text { Sweet } \\
\text { potatoes }\end{array}$ & 15.2 & 0.23 & 536 \\
\hline Sunflower & 15.5 & 0.99 & 355.1 \\
\hline \multicolumn{4}{|l|}{ Legumes } \\
\hline Groundnuts & 63.4 & 0.35 & 548.3 \\
\hline Cowpeas & 14.8 & 0.24 & 121.1 \\
\hline Soyabeans & 10.2 & 0,48 & 442.3 \\
\hline others & 6.4 & 0.21 & 96.6 \\
\hline
\end{tabular}

Source (CAP data). * Average calculated over four farming seasons.

Cover crops were planted by $14 \%$ of the households using cowpeas, sun hemp (Crotalaria juncea), groundnuts and velvet beans (Mucuna pruriens). Legumes such as common beans and cowpeas are traditionally intercropped with the main cereal crops in both CA and CV systems. This enables the legumes to creep onto the cereal crops, resulting in higher yields compared to when they are grown as sole crops (Biodiversity Community Network, 2006). Crop Legumes are important in biological nitrogen fixation and have the potential to improve soil fertility. However, their adoption is mediated by factors such as accessibility to good quality seed and markets. The successful incorporation of crop legumes in reducing land degradation would therefore depend on how well such bottlenecks that constrain their current adoption are addressed.

Field observations and key informant interviews revealed that maize and cotton grown under CA produced more biomass than those from CV fields. This was confirmed by the estimates of biomass production from maize fields (Table 3). With grain yields ranging between 2.4 and $4.8 \mathrm{t} \mathrm{ha}^{-1}$, biomass production was estimated at between 2.9 and $5.9 \mathrm{t} \mathrm{ha}^{-1}$ for CA systems. Average grain yield levels of 2.1 to $2.8 \mathrm{t} \mathrm{ha}^{-1}$ resulted in biomass production estimates of between 2.6 and $3.4 \mathrm{tha}^{-1}$ for the $\mathrm{CV}$ systems.

Table 3. Maize grain and biomass production in conservation and conventional agricultural systems

Conservation Agriculture

Maize grain
$\left(\mathrm{t} \mathrm{ha}^{-1}\right)$ Cropresidues $\left(\mathrm{t} \mathrm{ha}^{-1}\right) \quad$ Maize grain $\left(\mathrm{t} \mathrm{ha}^{-1}\right)$
Study

Crop residues $\left(\mathrm{t} \mathrm{ha}^{-1}\right)$

\begin{tabular}{ccccc}
3.6 & 4.4 & 2.1 & 2.6 & Current study \\
3.8 & 4.6 & 2.8 & 3.4 & Umar et al., (2011a) \\
4.8 & 5.9 & 2.8 & 3.4 & Langmead (2004) \\
3 & 3.7 & 2.1 & 2.6 & FAO (2011) \\
2.4 & 2.9 & 2.2 & 2.7 & Haggblade \& Tembo (2003) \\
\hline
\end{tabular}

Biomass production was estimated from grain yield and harvest index using the formula:

Biomass $=\left[(1 \text {-harvest index })^{*}\right.$ grain yield $] /$ harvest Index. Harvest index $=0.45$. 
In CA systems, at least $30 \%$ of the soil surface must be covered throughout the year. Biomass retention of $3 \mathrm{tha}^{-1}$ is needed to meet this threshold (FAO, 2011b). Crop yields were consistently higher from CA than from CV fields (Table 3). In a related study with the same sample, it was found that yield levels of $5.2 \mathrm{t} \mathrm{ha}^{-1}$ could be obtained by switching to the basin system despite a continued under application of mineral fertilizers of only 30 $\mathrm{kg} \mathrm{ha}^{-1}$ (Umar at al., 2011a), which is significantly below the recommended application rates of 225 to $325 \mathrm{~kg}$ $\mathrm{ha}^{-1}$ for CA systems. Achieving higher yields in the short term could motivate CA farmers to continue with their current practices of under replacing nutrients.

Field observations revealed that in most cases crops residues were not retained on the fields but were used as animal fodder, for household fuel purposes or burnt. In maize fields, the mature plants were cut and gathered in vertical bundles which were then left to dry within the fields. The maize cobs were then removed and subsequently shelled. The residues were handled in different ways: removed by the farmers and stored to be fed to the livestock during the dry season; left in the field and grazed upon by livestock in situ; burnt as a pre tillage land preparation measure at the commencement of the farming season; used as fuel wood; or used as mulch. With an average of 7.6 head of cattle (Table 4), an estimated 6.9 tons per hectare of crop residues would be needed to meet their fodder requirements. Clearly, the crop residues produced were insufficient for meeting competing household needs as well as retaining some in the field for soil fertility improvement purposes.

Table 4. Livestock/Poultry ownership over four year period

\begin{tabular}{|c|c|c|c|c|c|c|c|}
\hline \multirow[t]{2}{*}{ Livestock/Poultry } & \multicolumn{4}{|c|}{ Year } & \multirow{2}{*}{$\begin{array}{l}\text { Average no. of } \\
\text { livestock per } \\
\text { household over } \\
\text { period }\end{array}$} & \multirow{2}{*}{$\begin{array}{l}\text { Average } \% \\
\text { of households } \\
\text { owning } \\
\text { livestock }\end{array}$} & \multirow{2}{*}{$\begin{array}{l}\text { Estimated } \\
\text { annual total } \\
\text { fodder } \\
\text { requirements } \\
\text { (tons/year) }\end{array}$} \\
\hline & 2007 & 2008 & 2000 & 2010 & & & \\
\hline cattle & 6.7 & 7.5 & 8 & 8.3 & 7.6 & 44.9 & 6.9 \\
\hline goats & 8.1 & 8.6 & 7.6 & 8.6 & 8.2 & 37 & 1.5 \\
\hline pigs & 4.2 & 4.2 & 4.4 & 4.3 & 4.3 & 52.8 & 1.6 \\
\hline chickens & 14.4 & 12.4 & 13.8 & 20.2 & 15.2 & 22.5 & 0.6 \\
\hline $\mathrm{N}$ & 640 & 535 & 486 & 424 & & & \\
\hline
\end{tabular}

Total daily intake was estimated at $2 \%$ of bodyweight.

According to FAO (2011b), partial decomposition losses due to activity by termites and other soil organisms further limits the quantity of crop residues that are available for retention as soil cover. The communities devised the practice of dry season communal grazing for supplementing the limited crop residues available to livestock owning households. These local institutions on communal grazing have great effect on the crop residues that remain at the end of the season. Before harvest, local rules demand that livestock are restricted to kraals. Households that allow their livestock to graze on neighbours' crops risk being reported to the headman or chief, and being fined. After harvest, livestock are allowed to roam around and graze on crop residues from any fields as the fields are then considered as communal grazing grounds. This reduces the quantity of crop residues available for use as soil cover. For cotton and tobacco crops in Zambia, burning of crop residues is mandatory for phytosanitary reasons (Erenstein, 2003). This regulation precludes their use as soil cover. The removal or burning of crop residues can accelerate erosion and deplete soil fertility. Retaining crop residues in the fields has benefits such as increase in SOC content, nutrient recycling, soil fertility enhancement, reduction in soil erosion and carbon sequestration (Lal, 1997; Unger, 1994). The CA principle of a minimum of 30\% soil cover through either growing crops or crop residues is thus extremely difficult to adhere to in the study areas. As argued by Lahmar et al. (2011) in the context of the Sahelian region, CA may hardly succeed if other sources of biomass are not found.

\subsection{Reducing Land Degradation: Role of Faidherbia albida and Improved Fallows}

Faidherbia albida has been promoted as part of the CA package for mitigating the effects of land degradation caused by conventional agriculture. It is claimed that it adds nutrients to the soils under its canopy (Mokgolodi et 
al., 2011; Saka et al., 1994). In this study, the total nitrogen, organic carbon and potassium levels were significantly higher $(\mathrm{p}=0.009)$ under the $F$. albida canopies than outside them (Table 5). Total nitrogen, organic carbon and exchangeable potassium levels were respectively $42 \%, 31 \%$ and $25 \%$ higher under the canopies than outside. The available phosphorus levels in the soil were high regardless of distance from the tree $(\mathrm{p}=0.26)$ and there was no clear effect on their levels with distance from the canopy. The results revealed that the mature $F$. albida trees supply significant amounts of total nitrogen, organic carbon and potassium to the soils under their canopies and improve the soil fertility (Umar et al., 2011b). The high phosphorus levels found here are consistent with those from the soils sampled from the CA and CV fields reported in section 3.1. Both of these results contradict the phosphorus deficient scenarios reported in the literature (Cardoso \& Kuyper, 2006) and commonly advanced as part of the land degradation narrative.

Table 5. Nutrient levels under and outside Faidherbia albida canopies

\begin{tabular}{ccccc}
\hline Nutrient & $\begin{array}{c}\text { Level under } \\
\text { tree canopy }\end{array}$ & $\begin{array}{c}\text { Level } \\
\text { outside tre } \\
\text { canopy }\end{array}$ & $\begin{array}{c}\text { Increase in } \\
\text { nutrient level } \\
\text { due to effect } \\
\text { of tree }\end{array}$ & $\begin{array}{c}\text { Mineral fertilizer } \\
\text { equivalent }(\mathrm{kg})^{*}\end{array}$ \\
\hline $\begin{array}{c}\text { Total } \\
\text { Nitrogen } \\
\left(\mathrm{kg} \mathrm{ha}^{-1}\right)\end{array}$ & $\begin{array}{c}4420^{\mathrm{a}} \\
(2527.2)\end{array}$ & $\begin{array}{c}3120^{\mathrm{b}} \\
(4490.2)\end{array}$ & 1300 & 390 \\
$\begin{array}{c}\text { Potassium } \\
\left(\mathrm{kg} \mathrm{ha}^{-1}\right)\end{array}$ & $\begin{array}{c}1007^{\mathrm{a}} \\
(269.9)\end{array}$ & $802^{\mathrm{b}}(216.6)$ & 202.8 & 2443 \\
$\begin{array}{c}\text { Phosphorus } \\
\text { Organic }\end{array}$ & $66.5^{\mathrm{a}}(56.8)$ & $63.2^{\mathrm{a}}(55.7)$ & 0 & $\mathrm{n} / \mathrm{a}$ \\
carbon & $41080^{\mathrm{a}}$ & $31460^{\mathrm{b}}$ & & $\mathrm{n} / \mathrm{a}$ \\
$\left(\mathrm{kg} \mathrm{ha}^{-1}\right)$ & $(22750)$ & $(21785)$ & 9620 & \\
\hline
\end{tabular}

*equivalent to D- Compound fertilizer $\left(\mathrm{N} \mathrm{P}_{2} \mathrm{O}_{5}: \mathrm{K}_{2} \mathrm{O}, 10: 20: 10\right)$. This is the most commonly used top dressing fertilizer in Zambia. The values in parentheses are standard deviations.

The respondents seemed to be aware of the soil fertility improving benefits of $F$. albida as $93 \%$ of them said they had planted the tree as a result of their conviction of its soil fertility improvement benefits while the rest (7\%) were experimenting to see whether the tree improved soil fertility. Mature stands of naturally growing F. albida trees were reported as present in their cultivated fields by $13 \%$ of the households while $33.4 \%$ reported having planted it and had immature trees growing in their CA fields. Analysis of the panel survey data showed that households had an average of 33 F.albida trees in 2009 which increased to 48 in 2010. They planted on average 90, 69, and 45 trees during the 2007/2008, 2008/2009 and 2009/2010 farming seasons per household, but most of them (67.2\% ) did not survive into the following season (Umar \& Nyanga, 2011). Survival rates of F. albida seedlings in smallholder farmers' fields are usually low and range between 15 and 60\% (Golden Valley Agricultural Research Trust [GART], 2008). The economic or liberal approach may explain the behavior of the households with regards to $F$. albida in the study areas. The provision of free $F$. albida seedlings and training on its management for $\mathrm{CA}$ farmers has arguably spurred its increased adoption.

Agroforestry has been promoted as a soil fertility enhancing system in conventional systems as well as CA systems. Improved fallows, which incorporated leguminous trees and herbs into smallholder farming systems, were tested in Eastern Zambia. Short duration tree fallows were promoted in response to declined soil fertility characterized by severe nitrogen deficiency resulting from nearly continuous maize cultivation with little or no nutrient inputs (Kwesiga, Franzel, Place, Phiri, \& Simwanza, 1999; Kabwe, 2010). The plant species commonly used were Tephrosia vogelli, Sesbania sesban, Tephrosia candida and Cajanus cajan. Almost three-quarters (71\%) of a sample of farmers who had improved fallows during the 1996/1997 farming season maintained them over the next three farming seasons. Approximately 77500 farmers had improved fallows in 2003 (Kwesiga et al., 2003). During the current study, it was observed that over half of the CA farmers interviewed during the survey had either a Tephrosia candida or Sesbania sesban tree around their homestead. Only one household had a one acre field of two -year -old Tephrosia shrubs. This was the only visible evidence that they had participated 
in the agroforestry programme promoted in the province during the last two decades. This result is a far cry from the figures reported in 2003 by Kwesiga et al. (2003). These findings seems to confirm the dis-adoption that occurs when a project ends and incentives, which act as pull factors for technology adoption, are removed.

\subsection{CA Promotion and Incentives}

The provision of incentives to CA farmers has characterized CA promotion in Zambia. For instance, the Conservation Agriculture Scaling up for Increased Productivity and Production Project (CASPP) and the Farmer Input Support Response Initiative (FISRI), two programmes aimed at up-scaling CA in 12 districts of Zambia, both provided redeemable input vouchers worth 500000 Zambian Kwacha (USD100) per lead farmer. In addition to the voucher scheme, CASSP directly procured 8500 seedlings of $F$. albida, 1.5 tons of velvet bean seed and 20 tons of cowpea seed for inclusion in rotations (FAO, 2011a). Both projects had the goal of training 58800 beneficiary farmers, 45 Ministry of Agriculture staff and 3920 lead farmers in CA so as to enable its successful expansion. With the attachment of incentives to technology adoption, it is difficult to evaluate the adoption of CA technologies by the sampled households in the study area in particular; whether it has come about through their conviction of land degradation resulting from their conventional agriculture practices, as framed through the Malthusian narrative, and the need for them to reverse it by adopting CA practices, or whether it was merely to access the incentives.

The use of the lead farmer extension model, in which local farmers are recruited and trained to demonstrate the benefits of CA to and teach their colleagues, has also served as a pull factor. The lead farmers, called farmer coordinators, are each given four electronic vouchers (each valued at 400 Zambian Kwacha) redeemable at selected agro-dealers, while the farmers under the farmer coordinators, called contact farmers, receive one voucher each. In addition, all the CA farmers also receive $100 \mathrm{~F}$. albida seedlings, cassava cuttings and legume seeds. Most farmer coordinators invariably recruited members of their extended families and their friends. Thus many farmers were 'pulled' into adopting CA because a relative or friend farmer coordinator had invited them, and were partly incentivized to accept supply of free planting materials and vouchers.

\subsection{Input Application in CA Systems}

There was evidence of high precision in the application of mineral fertilizers and manure in CA systems. The CFU (CFU, 2009b) advises farmers to place 8g of basal fertilizer $\left(\mathrm{N}: \mathrm{P}_{2} \mathrm{O}: \mathrm{K}_{2} \mathrm{O}, 10: 20: 10\right)$ at the bottom of every basin two months prior to sowing. This is equivalent to $125 \mathrm{~kg} \mathrm{ha}^{-1}$ of basal fertilizer. For ripped fields, the advice is that a $100 \mathrm{ml}$ jar is filled with basal fertilizer which is then spread along the furrows, covering a length of either 10 or 20 paces. This is equivalent to either $200 \mathrm{~kg}$ or $100 \mathrm{~kg} \mathrm{ha}^{-1}$ of basal fertilizer, depending on the length covered. For applying top dressing fertilizer $(46 \% \mathrm{~N})$, the recommended practice is to place $6 \mathrm{~g}$ of the fertilizer into a small furrow scratched next to each stand of maize. For manure, the recommended practice was to scatter one double handful of manure per basin which is equivalent to $4 \mathrm{t} \mathrm{ha}^{-1}$. Manure was used on less than half (only $44 \%$ ) of the CA fields.

Over half of the respondents seemed to have correct agronomic knowledge on how to apply basal fertilizer and over three quarters for top dressing fertilizer. Manure application increases carbon sequestration rates due to its ability to enhance residue carbon in the soil (Koga \& Tsuji, 2009). Manure also returns nutrients to the soil and improves its physical structure. The CA practice of 'precision in input application' minimizes the problem of soil acidification exacerbated by mineral fertilizers use. Chemical land degradation resulting from the misapplication of mineral fertilizers (a practice common under conventional agriculture) reportedly caused the loss of $15 \%$ of the arable land in Zambia between 1986 and 2006 (Biodiversity Community Network, 2006). The correct application of mineral fertilizers under CA is thus predicted to reduce the land degradation previously associated with its misapplication.

\subsection{The Impacts of Agricultural Policies on CA Practice and Land Degradation}

Since independence in 1964, Zambia's agricultural policy has been biased towards maize production. The regime subsidized maize production and marketing for two related reasons; to ensure adequate maize production at low consumer prices for the urban population, and to raise the incomes of rural based smallholder farmers. This has resulted in a badly distorted and lop-sided sector dominated by maize (Farrington \& Saasa, 2002). The implementation of the World Bank supported Structural Adjustment Programme in 1991 saw the removal of subsidies in the agricultural sector and a subsequent contraction in the use of mineral fertilizers and hybrid seed, resulting in generally poor performance of the agricultural sector (Deininger \& Olinto, 2003).

In 2002, the Government of Zambia introduced the Fertilizer Support Programme (FSP), a government subsidy program, to provide subsidized input packages to smallholder maize farmers for three farming seasons (World 
Bank 2010) but is now in its $10^{\text {th }}$ season. The FSP was designed so that qualifying farmers contribute $25-40 \%$ of the cost of inputs to receive a package of eight $50 \mathrm{~kg}$ bags of mineral fertilizer and $20 \mathrm{~kg}$ of hybrid maize seed. Each FSP package is sufficient for one hectare and is expected to result in maize yield of 3 tons ha ${ }^{-1}$. In 2007, the FSP accounted for 35 - 60\% of the total national budget for Agriculture (World Bank, 2007; Xu, Burke, Jayne, \& Govereh, 2009), while about $80 \%$ of the discretionary budget for poverty reducing programs was spent on FSP and the Food Reserve Agency (Haankuku, 2010). Jayne et al. (2007) reported figures of $63 \%$ and $80 \%$ in 2004 and 2005 respectively of agricultural ministry expenditure on FSP.

The National Agricultural Policy (2004-2015) provides the overall vision, policy and strategic framework for the development of agriculture in Zambia (World Bank, 2007). It acknowledges the need to pay special attention to sustainable productivity of various farming systems especially among smallholder farmers. It mentions the promotion of conservation farming and rainwater harvesting technologies as a strategy for the promotion of soil, vegetation and water in order to sustain agricultural production (GRZ, 2004). The Fifth National Development Plan (2006-2010) listed the increased use of better and sustainable farming practices, including conservation farming and low input agriculture as one option for increasing overall crop production (GRZ, 2006). The Sixth National Development Plan (2011-2015) aims to promote soil management for sustainable agricultural production and growth by promoting appropriate conservation farming methods through a program on conservation agriculture and agro-forestry (GRZ, 2011). The National Adaptation Programme of Action (NAPA) document on climate change identified conservation tillage for moisture conservation as a key climate change adaptation measure. This is to be achieved through the buildup of organic matter and the consequent reduction in run-off, improved nutrient retention and reduced soil erosion (GRZ, 2007).

Zambia is a signatory to the Comprehensive African Agriculture Development Programme (CAADP). CAADP is an initiative by the African Union aimed at helping African countries reach higher paths of economic growth through agriculture-led development. Its vision for agricultural reform in Africa is for an average annual growth rate of $6 \%$ in agriculture by 2015 . Member countries have committed to allocating $10 \%$ of their national budgets to agriculture by 2008 (Govereh et al., 2009:p13; CAADP, 2011). CAADP consists of four pillars. Pillar 1 is a framework on sustainable land and water management. Its aim is to extend the area under sustainable land and water management throughout SSA. In terms of this pillar, CA is recommended as one of the best sustainable land and water management practices (CAADP, 2009).

Despite its CAADP aspirations, Zambia's budgetary allocations to the agriculture sector have remained at less than $7 \%$ of total national budget (Govereh, Shawa, Malawo, \& Jayne, 2006; Africa Business, 2012), and actual disbursement of the funds has consistently fallen short of budgeted expenditure (Chiwele \& Sikananu, 2004). Out of the total allocation to the agricultural sector, FSP and the Food Reserve Agency (the parastatal maize buying agent), had a combined allocation of around $40 \%$, while agricultural research and extension received a meager $4 \%$. Of this $4 \%, 75 \%$ was for wages and salaries. This shows that public sector research and extension has become ineffective and almost faded into oblivion (Jayne et al., 2007). This puts a limit on the extension services that can be provided to smallholder farmers, especially in terms of newly introduced technologies like CA. It has also resulted in the continued production and dominance of maize. Maize grain (and thus the nutrients contained in the crop) is invariably transported out of its production areas where the nutrients are needed (usually rural areas) to urban centers. Since Zambia is among the most urbanized countries in Africa and about $82 \%$ of agricultural production is from rural smallholder farmers (CSO, 2000), nutrient mining is thus prevalent. This is arguably exacerbated by the government's maize-centric policy which has continued to pull farming households towards the production of maize, without adequately addressing the challenges that characterize smallholder farming in Zambia holistically.

CA promotion in Zambia has been and remains donor dependent. This has implications for its sustainability as donor funded projects have relatively short life spans characterized by five year project cycles. The government's support to the Ministry of Agriculture has not matched its rhetoric as evidenced by the gap between policies and their implementation. The provision of CA extension services has depended on donor funded non - governmental actors. The initiatives of these actors are limited by the policy environment which seems to ignore the implementation of sustainable land management.

\section{Relevance of the Land Degradation Narrative for Explaining Agro-Based Soil Degradation in Zambia}

In view of the results of this study, population pressure per se may not be the cause of the failure to maintain soil fertility in the smallholder farming sector. Most smallholders have access to more land than they cultivate during any given season. For most of them, the limitation is labour, seed and other inputs. The most proximate cause of the declining soil fertility seems to be the low levels of nutrient replacement through crop residue removal and low 
levels of organic and mineral fertilizer amendments. The expansion of cultivated areas, and resulting deforestation, is an option for many as the population pressure is not yet high enough to significantly limit the landholdings households have at their disposal and to spur intensification. Only $14 \%$ of Zambia's land with agricultural potential is currently being utilized (Mulemba, 2009). Land degrading farming practices are usually linked to poverty. However, nutrient mining through crop residue removal can also be attributed to wealthy households owning large herds of cattle. In such instances, it would not be poverty, but wealth that could be argued to be ultimately responsible for nutrient mining. Wealthy households may also be able to hire labor and expand their cultivated area by converting forests.

Soil analyses did not find any evidence of soil compaction in either CA or CV fields. The high exchangeable potassium and available phosphorus levels in the sampled soils are indicative of the variability that exists in soils in Zambia and hence the limitation of blanket statements about the deficiencies of these nutrients. CA is being promoted in areas which are believed to have been mined of nitrogen, phosphorus, potassium and other nutrients and whose soils have developed hoe/plough pans which restrict root development. These results show that this is not always the case and the rationale for CA promotion may need modification in this particular case. For instance, CA farmers are asked to use the heavy chaka hoe in order to break the plough/hand hoe pans. This may not be necessary in areas where there are no plough/hand hoe pans. Improvements in soil fertility resulting from CA are not yet evident. This is not a failure of CA, but a result of the incomplete adoption of the CA package which has proved extremely difficult for adoption in its entirety by the resource constrained households among whom it is being promoted.

\section{Conclusion}

One of the goals of Conservation Agriculture (CA) promotion in Zambia is to reduce agro-based environmental degradation through soil fertility improvement. This is to be achieved through minimum tillage, legume based crop rotations, retention of crop residues on fields, precision in input applications (mineral fertilizers and manure), and integration of the nitrogen fixing tree Faidherbia albida into the CA system. This study found that after five years of practicing CA, there is no evidence of the soil improvement benefits of CA due to the failure to incorporate its important soil fertility enhancing components. Mature stands of Faideherbia albida added significant quantities of total nitrogen, organic carbon and exchangeable potassium to soils under their canopies.

It was also found that some of the premises of CA promotion in Zambia, namely a break down in traditional soil fertility management strategies because of population pressure and very low levels of nutrients due to pervasive nutrient mining, did not hold in the study areas. For instance, the low total nitrogen and organic carbon levels in the soils were more likely associated with crop residue removal and low manure and mineral fertilizer amendments rather than population pressure. Phosphorus levels were high in all the study areas. Failure to incorporate the principle of crop residue retention under CA means that nutrient mining has continued despite the increase in crop yields that has been observed in the short term. There is a need to integrate more nutrient replacement strategies such as improved fallows. The long - term environmental benefits associated with CA will only be actualized if practices that return or supply nutrients to the soil and improve its fertility are adopted. It is also necessary for the Government of Zambia to implement its agricultural and supportive policies in ways that enhance the adoption of CA in particular and soil and water conserving practices in general. This could for instance be through the inclusion of legume seed to the subsidy package or provision of the subsidy through vouchers redeemable from agro-shops. The voucher system would allow CA farmers to purchase CA implements and a wide variety of seeds.

\section{Acknowledgements}

This study was funded by the Norwegian Ministry of Foreign Affairs (through the Norwegian Embassy in Lusaka) via the Conservation Agriculture Programme implemented by the Conservation Farming Unit. The sponsors did not play any role in study design; in the collection, analysis, and interpretation of data; in the writing of the report; and in the decision to submit the paper for publication. All the views expressed in this paper are entirely those of the author.

\section{References}

Africa Business. (2012). Agriculture suffers less funding in zambia's 2011 budget. Africa Business News. Last accessed 25th March 2012.

AGRA. (2011). Agra update:Soils. Nairobi: Alliance for a Green Revolution in Africa.

Ajayi, O. C., Place, F., Kwesiga, F., \& Mafongoya, P. (2006). Impact of natural resource management technologies. Fertilizer tree fallows in zambia. (Vol. Occasional Paper 05, pp. p1-16.). Nairobi, Kenya.: World Agroforestry Centre. 
Ayoub, A. T. (1994). Human induced soil degradation in africa. Paper presented at the 8th International Soil Conservation Conference., New Delhi, India.

Barbier, \& Edward, B. (2000). Links between economic liberalization and rural resource degradation in the $\begin{array}{llll}\text { developing } & \text { regions. } & \text { Agricultural 299-310. }\end{array}$ http://dx.doi.org/10.1016/s0169-5150(00)00091-8

Biodiversity Community Network. (2006). Analysis of existing national policies and legislation that enable or inhibit the wider use of underutilized plant species for food and agriculture in zambia. Lusaka, Zambia.: Global Facilitation Unit for Underutilized Species.

Biot, Y., Blaikie, P. M., Jackson, C., \& Palmer-Jones, R. (1995). Rethinking research on land degradation in developing countries (Vol. World Bank Discssion Paper No. 289). Washington, DC.: The World Bank. http://dx.doi.org/10.1596/0-8213-3329-1

CAADP. (2009.). Sustainable land and water management. The caadp pillar 1 framework. (pp. p 23). Pretoria, South Africa.: The New Partnership for Africa's Development (NEPAD).

CAADP. (2011). Zambia: Deal paves way for country to zambia to allocate 10pc of budget to agriculture. Retrieved 24th May 2011, from http://www.caadp.net/news/?p=958

Cardoso, Irene M., \& Kuyper, Thomas, W. (2006). Mycorrhizas and tropical soil fertility. Agriculture, Ecosystems \& Environment, 116(1-2), 72-84. http://dx.doi.org/10.1016/j.agee.2006.03.011

CFU. (2006). Reversing food insecurity and environmental degradation in zambia through conservation agriculture. Lusaka: Conservation Farming Unit.

CFU. (2009a). Conservation farming and conservation agriculture handbook for ox farmers in agro-ecological regions i and iia. 2009 edition. Lusaka: Conservation Farming Unit.

CFU. (2009b). Conservation farming and conservation agriculture handbook for hoe farmers in agro-ecological regions $i$ and iia-flat culture. 2009 edition. Lusaka: Conservation Farming Unit.

Chishala, B. H. (2007). Agricultural technologies and dissemination situation in zambia. Gaborone: Southern African Development Community.

Chivenge, P. P., Murwira, H. K., Giller, K. E., Mapfumo, P., \& Six, J. (2007). Long-term impact of reduced tillage and residue management on soil carbon stabilization: Implications for conservation agriculture on contrasting soils. Soil and Tillage Research, 94(2), 328-337. http://dx.doi.org/10.1016/j.still.2006.08.006

Chiwele, D. K., \& Sikananu, R. (2004). Agriculture development and food security in sub-saharan africa: Building a case for more support. A case study of zambia. Rome, Italy: Agriculture Policy Analysis Unit, Food and Agricultural Organization.

CSO. (2000). Zambia 2000 census of population and housing. Lusaka: Central Statistical Office.

CSO. (2003). Zambia 2000 census of population and housing. Agriculture analytical report. Lusaka, Zambia.: Central Statistical office.

CSO. (2011). 2010 census of population and housing zambia. Preliminary report. Lusaka: Central Statistical Office.

Deininger, K., \& Olinto, P. (2003). Why liberalization alone has not improved agricultural productivity in Zambia. Washington .D.C.: World Bank.

Diagana, B. (2003). Land degradation in subsaharan africa: What explains the widespread adoption of unsustainable farming practices? (pp. 1-13). Bozeman, MT, USA: Department of Agricultural Economics and Economics. Montana State University.

Drechsel, P., Gyiele, L., Kunze, D., \& Cofie, O. (2001a). Population density, soil nutrient depletion, and economic growth in sub-saharan africa. Ecological Economics, 38(2), 251-258. http://dx.doi.org/10.1016/s0921-8009(01)00167-7

Drechsel, P., Kunze, D., \& de Vries, F. P. (2001b). Soil nutrient depletion and population growth in sub-saharan africa: A malthusian nexus? Population and Environment., 22(4), 411-423. http://dx.doi.org/10.1023/a:1006701806772

Erenstein, O. (2003). Smallholder conservation farming in the tropics and sub-tropics: A guide to the development and dissemination of mulching with crop residues and cover crops. Agriculture, Ecosystems \& Environment, 100(1), 17-37. http://dx.doi.org/10.1016/s0167-8809(03)00150-6 
Eroarome, M. A. (1983). Country profile-zambia soils and topography. Retrieved 27th May 2011, from http://www.fao.org/ag/AGP/AGPC/doc/Counprof/zambia/zambia.htm\#_Toc131995463

FAO. (2010). What is conservation agriculture? Retrieved from http://www.fao.org/ag/ca Retrieved 14th August 2010.

FAO. (2011a). Socio-economic analysis of conservation agriculture in southern africa. REOSA Network Paper 02. Johannesburg, South Africa.

FAO. (2011b). Climatic risk analysis in conservation agriculture in varied biophysical and socio-economic settings of southern africa. Johannesburg: Regional Emergency Office for Southern Africa ( REOSA).

Farrington, J., \& Saasa, O. (2002). Drivers for change in zambian agriculture defining what shapes the policy environment. London.: Department for International Development (DFID).

Franzel, S. (1999). Socioeconomic factors affecting the adoption potential of improved tree fallows in africa. Agroforestry Systems, 47(1), 305-321. http://dx.doi.org/10.1023/a:1006292119954

GART. (2008). Golden valley agricultural research trust: 2007 yearbook. Lusaka: GART.

Govereh, J., Malawo, E., Lungu, T., Jayne, T., Chinyama, K., \& Chilonda, P. (2009). Trends and spatial distribution of public agricultural spending in zambia: Implications for agricultural productivity growth (Vol. ReSAKSS Working Paper No. 26). Pretoria, South Africa.: Regional Strategic Analysis and Knowledge Support System (ReSAKSS).

Govereh, J., Shawa, J., Malawo, E., \& Jayne, T. (2006). Raising the Productivity of Public Investments in Zambia's Agricultural Sector. Lusaka: Food Security Research Project. Working Paper No. 20.

GRZ. (2002). Zambia National Action Programme for Combating Desertification and Mitigating Serious Effects of Drought in the Context of the United Nations Convention to Combat Desertification. Lusaka: Ministry of Tourism, Environment and Natural Resources.

GRZ. (2004). National Agricultural Policy (2004-2015). Lusaka, Zambia.: Government of the Republic of Zambia.

GRZ. (2006). Fifth National Development Plan (2006-2010). Lusaka, Zambia.: Government of the Republic of Zambia.

GRZ. (2007). The National Adaptation Programme of Action (NAPA). Lusaka: Government of Republic of Zambia/Global Environment Facility/United Nationsa Development Fund.

GRZ. (2010). Integradted Land Use Assessment (ILUA). Zambia. 2005-2008. Lusaka.: Government of the Republic of Zambia.

GRZ. (2011). Sixth National Development Plan (2011-2015). Lusaka, Zambia.: Government of the Republic of Zambia.

Haankuku, C. (2010). A Retrospective Analysis and Priority Setting Exercise of Investments in Agricultural Research in Zambia. MSc. Thesis, University of Pretoria, Department of Agricultural Economics, Extension and Rural Development.

Haggblade, S., \& Tembo, G. (2003). Early Evidence on Conservation Farming in Zambia. Washington. D.C: International Food Policy Research Institute.

Heerink, N. (2005). Soil Fertility Decline and Economic Policy Reform in Sub-Saharan Africa. Land Use Policy, 22(1), 67-74. http://dx.doi.org/10.1016/j.landusepol.2003.08.002

Jayne, T. S., Govereh, J., Chilonda, P., Mason, N, Chapoto, A., \& Haantuba, H. (2007). Trends in Agricultural and Rural Development Indicators in Zambia (Vol. Working Paper No. 24.). Lusaka, Zambia.: Food Security Research Project.

Kabwe, G. (2010). Uptake of Agroforestry Technologies among Smallholder Farmers in Zambia. PhD Thesis, Lincoln University, Christchurch, New Zealand.

Koga, N., \& Tsuji, H. (2009). Effects of Reduced Tillage, Crop Residue Management and Manure Application Practices on Crop Yields and Soil Carbon Sequestration on an Andisol in Northern Japan. Soil Science \& Plant Nutrition, 55(4), 546-557. http://dx.doi.org/10.1111/j.1747-0765.2009.00385.x

Kwesiga, F., Akinnifesi, F. K., Mafongoya, P. L., McDermott, M. H., \& Agumya, A. (2003). Agroforestry Research and Development in Southern Africa during the 1990s: Review and Challenges ahead. 
Kwesiga, F., Franzel, S., Place, F., Phiri, D., \& Simwanza, C. (1999). Sesbania sesban Improved Fallows in Eastern Zambia: Their Inception, Development and Farmer Enthusiasm. Agroforestry Systems, 47(1), 49-66. http://dx.doi.org/10.1023/a:1006256323647

Lahmar, R., Bationo, B. A., Dan Lamso, N., Guéro, Y., \& Tittonell, P. (2011). Tailoring Conservation Agriculture Technologies to West Africa Semi-Arid Zones: Building on Traditional Local Practices for Soil Restoration. Field Crops Research, (In Press). http://dx.doi.org/10.1016/j.fcr.2011.09.013

Lal, R. (1997). Residue Management, Conservation Tillage and Soil Restoration for Mitigating Greenhouse Effect by $\mathrm{CO}_{2}$-Enrichment. Soil and Tillage Research, 43(1-2), 81-107. http://dx.doi.org/10.1016/s0167-1987(97)00036-6

Lal, R., \& Bruce, J. P. (1999). The Potential of World Cropland Soils to Sequester C and Mitigate the Greenhouse Effect. Environmental Science \& Policy, 2(2), 177-185.

Langmead, P. (2004). Hoe Conservation Farming of Maize in Zambia. Lusaka: www.langmead.com.

Marongwe, L. S., Kwazira, K., Jenrich, M., Thierfelder, C., Kassam, A., \& Friedrich, T. (2011). An African Success: The Case of Conservation Agriculture in Zimbabwe. International Journal of Agricultural Sustainability., 9(1), 153-161. http://dx.doi.org/10.3763/ijas.2010.0556

Mokgolodi, N., Setshogo, M., Shi, L., Liu, Y., \& Ma, C. (2011). Achieving food and nutritional security through agroforestry: a case of Faidherbia albida in sub-Saharan Africa. Forestry Studies in China 13(2): 123-131. http://dx.doi.org/10.1007/s11632-011-0202-y

Minitab. (2009). Minitab 15 Statistical Software. State College, USA. www.minitab.com: Minitab Inc.

Mulemba, H. (2009). The Livestock Sector in Zambia and Rising Food Prices. Country Briefing - Zambia. Manitoba, Canada.: International Institute for Sustainable Development.

Opio, C. (2001). Biological and Social Feasibility of Sesbania Fallow Practice in Smallholder Agricultural Farms in Developing Countries: A Zambian Case Study. Environmental Management, 27(1), 59-74. http://dx.doi.org/10.1007/s002670010134

PFAP. (2005b). Programme Completion Report 200-2005. Lusaka: Programme Coordination Unit.

R Development Core Team. (2011). R: A Language and Environment for Statistical Computing (Version R Studio ). Vienna: R Foundation for Statistical Computing.

Reicosky, D. C. (2009). Role of carbon in ecosystem services from conservation agriculture. Paper presented at the 4th World Congree on Conservation Agriculture.New Delhi, India.

Reij, C. P., \& Smaling, E. M. A. (2008). Analyzing Successes in Agriculture and Land Management in Sub-Saharan Africa: Is Macro-Level Gloom Obscuring Positive Micro-Level Change? Land Use Policy, 25(3), 410-420. http://dx.doi.org/10.1016/j.landusepol.2007.10.001

Rockström, J., Kaumbutho, P., Mwalley, J., Nzabi, A. W., Temesgen, M., Mawenya, L., ... Damgaard-Larsen, S. (2009). Conservation Farming Strategies in East and Southern Africa: Yields and Rain Water Productivity from On-Farm Action Research. Soil and Tillage Research, 103(1), 23-32. http://dx.doi.org/10.1016/j.still.2008.09.013

Saka, A. R., Bunderson, W. T., Itimu, O. A., Phombeya, H. S. K., \& bekeani, Y. M (1994). The effects of Acacia albida on soils and maize grain yields under smallholder farm conditions in Malawi. Forest Ecology and Management 64(2-3): 217-230. http://dx.doi.org/10.1016/0378-1127(94)90296-8

Scoones, I. (2001). Transforming soils: The dynamics of soil fertility management in africa. In I. Scoones (ed.). Dynamics and diversity. Soil fertility and farming livelihoods in africa. (pp. 1-5). London.: Earthscan Publications Ltd.

Scoones, I., \& Thompson, J. (1993). Challenging the populist perspective: Rural people's knowledge, agricultural researcch and extension practice. Sussex: Institute of Development Studies.

Siegal, P. B., \& Alwang, J. (2005). Poverty reducing potential of smallholder agriculture in zambia: Opportunities and constraints. Africa Region Working Paper Series No. 85. July 2005. Washington D.C.: The World Bank.

Siegel, P. B., \& Alwang, J. (2005). Poverty Reducing Potential of Smallholder Agriculture in Zambia: Opportunities and Constraints. Africa Region. (Vol. Working Paper Series No. 85). Washington. D.C.: World Bank.

So, H. B., Kirchhof, G., Bakker, R., \& Smith, G. D. (2001). Low input tillage/cropping systems for limited resource 
areas. Soil and Tillage Research, 61(1-2), 109-123. http://dx.doi.org/10.1016/s0167-1987(01)00182-9

Somasiri, S. (1994). Land Degradation: Causes and Impacts. Paper presented at the 8th International Soil Conservation Conference., New Delhi, India.

SPSS Inc. (2009). IBM SPSS Statistics Standard (Version 18 (Full Version)). New York: IBM Corporation.

Tittonell, P., Vanlauwe, B., Leffelaar, P. A., Shepherd, K. D., \& Giller, K. E. (2005). Exploring Diversity in Soil Fertility Management of Smallholder Farms in Western Kenya: Ii. Within-Farm Variability in Resource Allocation, Nutrient Flows and Soil Fertility Status. Agriculture, Ecosystems \& Environment, 110(3-4), 166-184. http://dx.doi.org/10.1016/j.agee.2005.04.003

Umar, B. B., Aune, J. B., \& Lungu, O. I. (2011b). Does Faidherbia albida Improve the Fertility of Soils in Smallholder Conservation Agriculture Systems in Southern and Eastern Zambia? Paper presented at the Regional Conservation Agriculture Symposium, Johannesburg, South Africa.

Umar, B. B., Aune, J. B., Johnsen, F. H., \& Lungu, O. I. (2011a). Options for Improving Smallholder Conservation Agriculture in Zambia. Journal of Agricultural Sciences, 3(3), 50-62. http://dx.doi.org/10.5539/jas.v3n3p50

Umar, B. B., \& Nyanga, P. H. (2011). IntegratingConservation Agriculture with Trees: Trends and Possibilities among Smallholder Farmers. Paper presented at the 5th World Congress of Conservation Agriculture incorporating 3rd Farming Systems Design Conference, Brisbane, Australia.

UN. (1994). United Nations Convention to Combat Desertification in those Countries Experiencing Serious Drought and/or Desertification, particularly in Africa. New York.: United Nations.

Unger, P. W. (Ed.). (1994). Managing agricultural Residues. Boca Raton: Lewis Publishers.

Varvel, G. E., \& Wilhelm, W. W. (2011). No-Tillage increases Soil Profile Carbon and Nitrogen under Long-Term Rainfed Cropping Systems. Soil and Tillage Research, In Press, Corrected Proof. http://dx.doi.org/10.1016/j.still.2011.03.005

Vlek, P. L.G., \& Tamene, L. (2009). Conservation Agriculture: Why? Paper presented at the 4th World Congress on Conservation Agriculture. Innovations for Improving Efficiency, Equity and Environment., New Delhi, India.

Vogt, J. V., Safriel, U., Von Maltitz, G., Sokona, Y., Zougmore, R., Bastin, G., \& Hill, J. (2011). Monitoring and assessment of land degradation and desertification: Towards new conceptual and integrated approaches. Land Degradation \& Development, 22(2), 150-165. http://dx.doi.org/10.1002/ldr.1075

World Bank. (2007). Project performance assessment report. Republic of zambia emergency drought recovery project. Washington, DC.: Sector Thematic and Global Evaluation Division, World Bank.

World Bank. (2010). Zambia: Impact assessment of the fertilizer support program, analysis of effectiveness and efficiency (Vol. Report No. 54864-ZM). Washington, DC.: Agriculture and Rural Development. Africa Region. Sustainable Development Department. World Bank.

Xu, Z., Burke, W. J., Jayne, T. S., \& Govereh, J. (2009). Do input subsidy programs "crowd in" or "crowd out" commercial market development? Modeling fertilizer demand in a two-channel marketing system. Agricultural Economics, 40(1), 79-94. http://dx.doi.org/10.1111/j.1574-0862.2008.00361.x

\section{Notes}

Note 1. A Livestock Unit is a unit that represents an animal of $250 \mathrm{~kg}$ live weight and is used to aggregate different species and classes of livestock as follows; cattle: 0.5 ; goat and sheep: 0.1 ; pig: 0.2 ; chicken and other poultry : 0.02 . 